\title{
DISTRIBUTION OF RARE AND ENDANGERED AMPHIBIANS AND REPTILES IN PRIMORSKY KRAI (FAR EAST, RUSSIA)
}

\author{
Irina V. Maslova ${ }^{1}$, Ekaterina Yu. Portnyagina ${ }^{2}$, Darja A. Sokolova ${ }^{2}$, \\ Polina A. Vorobieva ${ }^{2}$, Mikhail V. Akulenko ${ }^{3}$, Arseniy S. Portnyagin ${ }^{2,4}$, Alexey A. Somov \\ ${ }^{1}$ Federal Scientific Centre of the East Asia Terrestrial Biodiversity, Far Eastern Branch of RAS, Russia \\ e-mail: irinarana@yandex.ru \\ ${ }^{2}$ Far Eastern Federal University, Russia \\ e-mail:semenkaty@gmail.com,daria_1844@mail.ru,medusa8800@mail.ru \\ ${ }^{3}$ Gidrotekhnika Ltd., Russia \\ e-mail:animals06@bk.ru \\ ${ }_{4}^{4}$ Institute of Chemistry, Far Eastern Branch of RAS, Russia \\ e-mail:arsuha@gmail.com \\ ${ }^{5}$ Pacific Research Fisheries Centre (TINRO-Centre), Russia \\ e-mail: alekseysomoff@gmail.com
}

Received: 20.04 .2018

\begin{abstract}
Information is given on new findings of five rare and endangered species of amphibians and reptiles inhabiting the Primorsky Krai: Onychodactylus fischeri, Pelodiscus maackii, Takydromus wolteri, Oocatochus rufodorsatus and Hebius vibakari. New locations are presented for the studied amphibians and reptiles. For the first time, Onychodactylus fischeri is reported here for the Partizanky Ridge, thus expanding its known habitat range in the south-western direction. Data on Takydromus wolteri, Oocatochus rufodorsatus and Hebius vibakari findings in western Primorsky Krai are provided for the first time. Habitat borders of Takydromus wolteri in the northern part of its distribution has been updated in various directions: to the west (Khankaysky District), north (Krasnoarmeysky District) and northeast (Olginsky District). The current model of habitat range and breeding places of Khankaysky population of Pelodiscus maackii has been demonstrated, taking into account submerging sandy spits on the western coast of Lake Khanka in 2014-2017. Rivers flowing into Khanka from the western site were shown to play an important role for inhabitance and reproduction of this species. Detailed information on distribution of Hebius vibakari in Primorsky Krai is given for the first time. This species is indicated to be common and sometimes numerous in the south and central parts of Primorsky Krai. The current state of this species' population was researched at locations indicated previously in the references. Some Protected Areas were analysed in the way they protect rare species of the Far Eastern herpetofauna. Hebius vibakari occurs consistently in the Ussuriysky State Nature Reserve, Kedrovaya Pad State Nature Reserve and Land of the Leopard National Park. Within their borders, the Bikin National Park and Udegeyskaya Legenda National Park are shown to have no effect on conserving populations of Pelodiscus maackii and Oocatochus rufodorsatus inhabiting basins of the River Bikin and River Bolshaya Ussurka. Their populations are distributed to the west of the national parks. Organising new Protected Areas is urgent for the Primorsky Krai in its western part (River Komissarovka basin) and in its south-eastern part (Livadiysky Ridge).
\end{abstract}

Key words: Amphibia, distribution, rare species, Reptilia, Russian Far East

\section{Introduction}

In present time, there are 25 amphibian and reptile species inhabiting Primorsky Krai. Five of these species are in the Red Data Book of the Russian Federation (2001): Long-tailed Salamander Onychodactylus fischeri (Boulenger, 1886), Northern Chinese Softshell Turtle Pelodiscus maackii (Brandt, 1857), Slander Racer Orientocoluber spinalis (Peters, 1866), Beauty Snake Orthriophis taeniurus (Cope, 1861), and Red-backed Rat Snake Lycodon rufozonatum Cantor, 1842.

The Red Data Book of Primorsky Krai (2005) includes six species: Onychodactylus fischeri,
Rana rugosa Schlegel, 1838 (now considered as Glandirana emeljanovi Nikolskii, 1913), Pelodiscus maackii, Orientocoluber spinalis, Red-backed Rat Snake Oocatochus rufodorsatus (Cantor, 1842), and Lycodon rufozonatum.

However, the next edition of the Red Data Books, delayed by four years already due to certain reasons, is planned to exclude both the species Glandirana emeljanovi and Orthriophis taeniurus. Their inhabitance on the Russian territory has not been proved by the moment. While the former species remained in the Red Data Book of Primorsky Krai (2005) and was excluded from the Red Data Book of the Rus- 
sian Federation (2001), the latter one went the opposite way. It was excluded from the Red Data Book of Primorsky Krai (2005) and remained in the Red Data Book of the Russian Federation (2001).

Both the next edition of the Red Data Book of the Russian Federation (2001) and the Red Data Book of Primorsky Krai (2005) are planning to include a new species, the Mountain Grass Lizard Takydromus wolteri (Fischer, 1885), whose main anthropogenic threat is multiple spring and autumn fires, specific for Primorsky Krai (Maslova, 2008). Recently, a lot of works have been devoted to studying various biological and ecological aspects of Takydromus wolteri, as little information was available about this vulnerable species (Ota et al., 2002; Chen et al., 2003; Ku \& Lee, 2004; Lee \& Ku, 2004; Zhang \& Ji, 2004; Xu et al., 2008; Ra et al., 2011; Jin et al., 2013; Yu \& Ji, 2013; Suh et al., 2016). Besides, the Japanese Keelback Hebius vibakari (Boie, 1826), which has recently changed its taxonomic status from Amphiesma to Hebius (Guo et al., 2014), will be included into the appendix of the Red Data Book of the Russian Federation (2001) in the rarity category 4 as «species with undefined status».

This article provides information on the distribution of five rare and endangered species of amphibians and reptiles presented in either mentioned above Red Data Books or planned to be included into their next editions: Onychodactylus fischeri, Pelodiscus maackii, Takydromus wolteri, Oocatochus rufodorsatus, Hebius vibakari.

We decided not to include Orientocoluber spinalis, and Lycodon rufozonatum in our work, because after the description of their findings in the Primorsky Krai (Solkin, 1990; Kharin \& Akulenko, 2008) no more recent information could be gathered.

Due to large time intervals lying between longterm herpetological research in the Primorsky Krai (Emelyanov, 1929; Korotkov, 1985; Kuzmin \& Maslova, 2005), distribution ranges of rare species are still not clear, maps reflecting recent distribution of amphibians and reptiles as well as rare species have not been prepared by the moment.

Amphibians are the most studied in this respect. Kuzmin \& Malsova (2005) and Kuzmin (2012) provided detailed maps with findings of all Far Eastern amphibians being recorded over there. Maps covering snakes' distribution in the Primorsky Krai were published only by Emelyanov (1929). Findings of various amphibians and reptiles in certain regions of Primorsky Krai were indicated by Adnagulov \& Oleinikov (2006). More than ten years ago, general map of the Northern Chinese Softshell Turtle's distribution in the Russian Far East was prepared (Adnagulov \&
Maslova, 2005). Distribution maps of the genus Takydromus lizards are given in Semenishcheva \& Maslova (2010). It is noteworthy that the Khankaysky District (western part of Primorsky Krai) remained «the tabula rasa» with respect to the herpetofauna, even though it was the first place settled by Russian colonists in the southern Far East. Research was carried out several times only for the Pelodiscus maackii population inhabiting Khanka Lake (Buldovskiy, 1936a,b; Cherepanov, 1990; Maslova, 2006).

Main international reptile and amphibian databases (Frost, 2017; Uetz et al., 2018) contain a number of defects in the sections on distribution of indicated species in the north-eastern part of their habitat due to the absence of recent information.

The status assessment of the natural populations of rare and endangered species is very urgent with re-discovery their habitats and distribution ranges. This is in line with the active development of the Russian Far East in accordance with the Federal Target Program «Economical and social development of Far East and Baikalskiy Region till 2025». It includes the establishing of a number of territories with priority development (TRD). Most of these are planned for the south of Primorsky Krai. The programme started last year and poorly elaborated with respect to the conservation of the biodiversity programme «Dalnevostochniy Gektar».

\section{Material and Methods}

Our maps were prepared based on target and additional information obtained during field work from 1986 to 2017. Besides, there was collected a large volume of information on new findings of amphibians and reptiles by colleagues and locals. This paper provides only information reliable at some points: obtained by professional zoologists, easily identified species in nature, obtained by different people or if a quality photo of a found animal is given along with the co-ordinates of the image location.

Besides certain findings of amphibians and reptiles, traces (tracks) of Pelodiscus maackii evidencing turtle's coming out of the water on the shore were taken into account. One of the ways to evaluate the population of the Northern Chinese soft-shell turtles (P. maackii) is to take into account traces (tracks) left after they came out of water onto the sandy beach. The following measurements were made: width of the track, its shape, the trace length (Adnagulov, 2008). When accounting P. maackii at points indicated in the paper, the overall number of turtles coming onto the beach was calculated after measuring the width of every found track to avoid 
double-accounting of the same individual.

The classification of amphibians and reptiles is following Adnagulov (2017).

Geographical positions of sampling and observations are given with respect to the state territory division into districts of Primorsky Krai in 2017 according to the law from 14.11.2001 No. 161-KZ «About state territory management of Primorsky Krai» (with changes on 05.06.2017). Acronyms of the Primorsky Krai districts are: Arsenievsky City District - ArCD; Anuchinsky District - AnD; Vladivostok City District - VlCD; Dalnegorsky City District - DlCD; Kirovsky District - KirD; Krasnoarmeysky District - KrD; Lazovsky District - LazD; Lesozavodsky District - LesD; Mikhaylovsky District - MikhD; Nadezhdinsky District - NadD; Olginsky District OlD; Partizansky City District - ParCD; Partizansky District - ParD; Pozharsky District - PozhD; Spassky District - SpD; Ussurysky City District - UsCD; Khankaysky District - KhanD; Khasansky District - KhasD; Khorolsky District - KhorD; Chernigovsky District - CherD; Shkotovsky District - ShkD; Yakovlevsky District - YakD; Marine Biological Station «Zapovednoe» of Far Eastern Federal University - MBS «Zapovednoe» FEFU; adult - ad; subadult - sad; juvenile - juv; larve - lar.

These are the abbreviations of Protected Areas, where the observations have been carried out: Ussurysky State Nature Reserve - UssSNR; Kedrovaya Pad State Nature Biosphere Reserve - KpSNR; Khankaysky State Nature Reserve KhankSNR; Far Eastern Marine Biosphere State Reserve - branch of the National Research Centre of Marine Biology of the Far Eastern Branch of RAS - FEMSNR; Land of the Leopard National Park - LLSNP.

Scheme maps were made, using the geographic information system QGIS 2.18.1.

\section{Results}

Below we present new data on distribution of reptiles and amphibians in the Russian Far East in general and particularly for Primorsky Krai. The points with the sign $\left\langle^{*}\right\rangle$ denote locations indicated for the first time here.

\section{Amphibians}

Onychodactylus fischeri (Boulenger, 1886) (Fig. 1)

1. ParCD, Tigroviy Village surroundings, Bolshoy Vorobey Ridge, middle current of Pigarev Brook; coniferous-broadleaved forest; some lar, 22.06.2015; 25.09.2016; 20.05.2017.

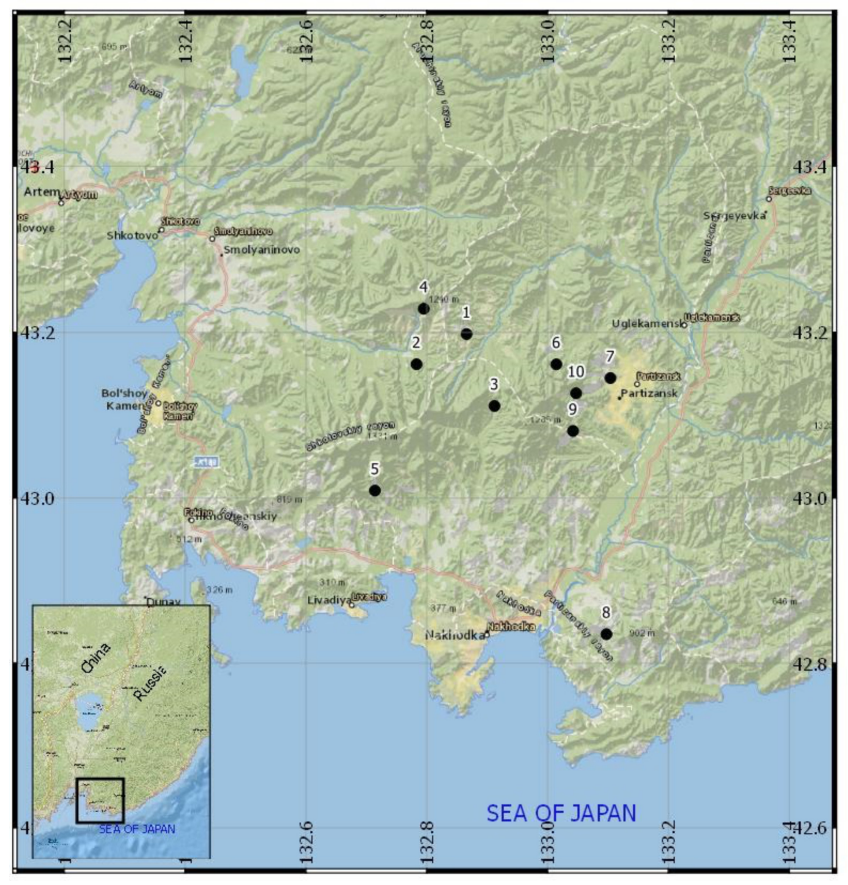

Fig. 1. Findings of Onychodactylus fischeri in the Primorsky Krai (Russia).

2. ParCD, Tigroviy Village surroundings, Livadiysky Ridge, Praviy Lesopilniy Brook; coniferous-broadleaved forest; 9 lar, 6.11 .2017 (V.B. Manaev, 2017: personal communication).

*3. ParD, Nakhodka City surroundings, Partizanskiy Ridge, headwater of the Manankina River; broadleaved forest with single coniferous trees, 2 ad (female), 25.04.2017.

4. ParCD, Lozovoy Village surroundings, outskirts of Skalistaya (Chitinza) Mt.; mean current of Lozoviy Brook; broadleaved forest; some lar, 12.08.2017.

5. ParCD, Krasnoarmeyskiy Village surroundings, outskirts of Skalistaya (Chitinza) Mt., upper reaches of Bolshoy Lipoviy Brook; coniferous-broadleaved forest; some lar, 15.06.2014; 11.08.2016.

6. ParCD, Partizansk Town surroundings, near Skalistaya (Chitinza) Mt., mean current of the River Kamenka; coniferous-broadleaved forest; some lar, 19.08.2017.

7. ParCD, Partizansk Town surroundings, near Skalistaya (Chitinza) Mt., mean current of the River Kamenka, broadleaved forest; some lar, 11.09.2016; 20.08.2017.

8. ParD, Livadiyski Ridge, upper reaches of River Pravaya Litovka, coniferous-broadleaved forest; some lar and some ad, 1.08.2013; 13.07.2014; 19.06.2016.

9. ShkD, upper reaches of Livadiyskaya Mt. Brooks, dark-coniferous forest; some lar and some ad, 2000-2014 (A.P. Levus, 2015: personal communication). 
10. ShkD, upper reaches of Vorobey Mt. Brooks, coniferous-broadleaved forest; some lar and some ad, 2000-2014 (A.P. Levus, 2015: personal communication).

\section{Reptiles}

Pelodiscus maackii (Brandt, 1857) (Fig. 2)

11. KhanD, Vtoraya Rechka River mouth, sandy beaches; 7 tracks, 22.06.2016; egg shells, 28.08.2016.

12. KhanD, Platono-Alexandrovskoe Village surroundings; sandy beaches of Khanka Lake shore; 14 tracks, 3 egg clutches, 23.06.2016.

13. KhanD, Turiy Rog Village surroundings; sandy beaches of Khanka Lake shore; 1 track, 21.06.2016; 3 tracks, 27.08.2016.

14. KhanD, northern part of Beloglinyaniy Cape, steep sandy slope near oak and pine forest; some egg clutches, 29.08.2016 (Citizen of Novokachalinsk Village, 2016: personal communication).

15. KhanD, Novokachalinsk Village surroundings; sandy beaches of Khanka Lake shore to the south of the village; 2 tracks, 29.08.2016.

16. KhanD, sandy beaches along the shore of Khanka Lake between Troitskoe and KamenRybolov settlements; 6 tracks, 2 egg clutches, 19.06.2016; 4 tracks, 02.09.2016.

17. KhanD, sandy beaches along the Khanka Lake between Troitskoe and Kamen-Rybolov settlements; 2 tracks, 19.06.2016.

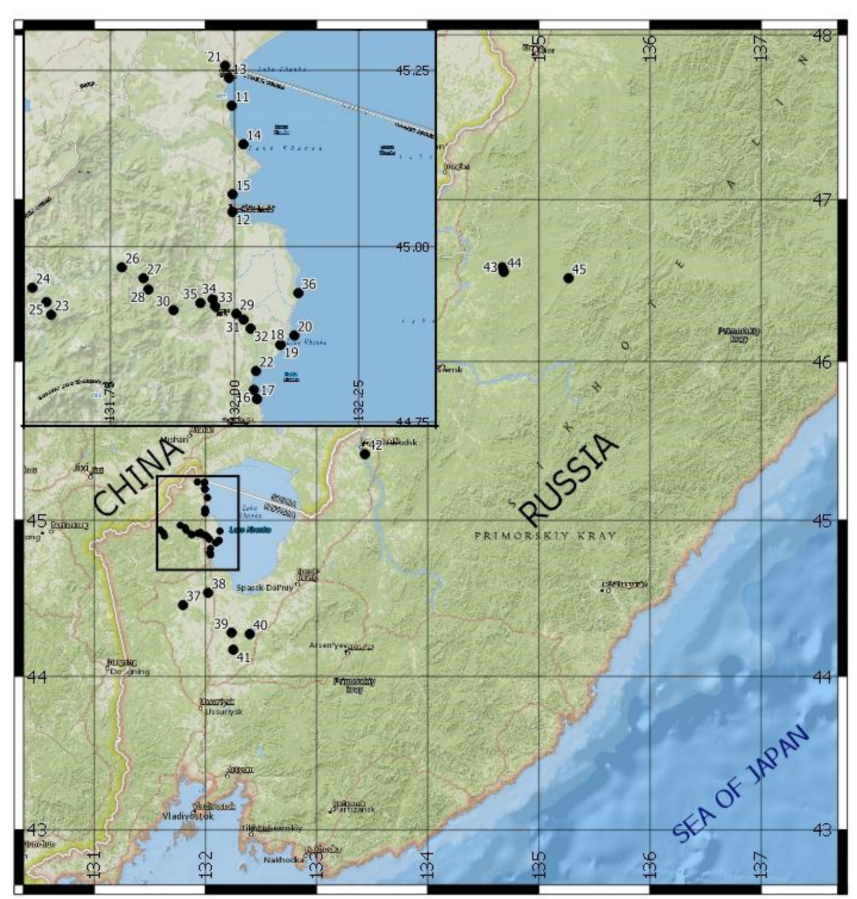

Fig. 2. Findings of Pelodiscus maackii in the Primorsky Krai (Russia).
18. KhanD, KhankSNR, sandy beach in the Kazachy Bay of Khanka Lake; psammophytic suffruticulose-mixed herbs associations, single bushes of willow; 4 ad, 15 tracks, 21.06.2017.

19. KhanD, KhankSNR, sandy beach in the Kazachy Bay of Khanka Lake, psammophytic suffruticulose-mixed herbs associations, single bushes of willow; 3 ad, 6 tracks, 2 empty egg clutches, 03.09.2016.

20. KhanD, KahnkSNR, sandy beaches of Przhevalsky Spit of Khanka Lake (due to water rise in the lake, this spit had transformed into a number of small isles by 2015, which merged by the second half of 2016 into the isolated island of $900 \mathrm{~m}$ length), psammophytic suffruticulosemixed herbs associations, single bushes of willow; 6 ad., 17 tracks, 22.06.2016; 12 tracks, 2 empty egg clutches, 03.09.2016; 17 ad, 18 tracks, 2 egg clutches, 21.06.2017; 12 tracks, 40 empty egg clutches, 22.09.2017.

21. KhanD, Turiy Rog Village surroundings, sandy beaches in the banks of the River Tur near the border line; some ad, annually (V.M. Kruchkov, 2016: personal communication).

22. KhanD, Troitskoe Village, sandy beach of «Troitskoe» recreation center; sandy beach of Khanka Lake shore; 2 ad, 18.06.2016 (the head of the «Troitskoe» recreation center, 2016; personal communication).

*23. KhanD, Dvoryanka Village surroundings, sandy beach in the bank of the Komissarovka River; 1 ad, 22.06.2017 (N.N. Avstrievskaya, 2017: personal communication, photo).

*24. KhanD, of Dvoryanka Village surroundings, Komissarovka River valley, bayou lakes; some ad, annually (K.K. Mayboroda, 2017: personal communication).

*25. KhanD, Dvoryanka Village surroundings, Adriashkino Lake of bayou type to the north from the village; some ad, annually (N.N. Avtrievskaya, 2017: personal communication).

*26. KhanD, of Komissarovo Village surroundings, bayou with sandy beaches near the bridge across the Komissarovka River; some ad, annually; 1 track, 05.07.2017 (P.T. Kuznetsov, 2017: personal communication).

*27. KhanD, Komissarovo Village surroundings, pebble-sandy spit below the village; some ad, several times (P.T. Kuznetsov, 2017: personal communication).

*28. KhanD, Komissarovka River valley, Kamyshovoe Lake, $10 \mathrm{~km}$ below Komissarovo Village; some ad, several times (P.T. Kuznetsov, 2017: personal communication). 
*29. KhanD, Ilyinka Village surroundings, Komissarovka River valley, 4 sandy pits connected with Komissarovka River; 1 ad, 2 sad, 12 tracks, 2 egg clutches, 20.06.2017.

*30. KhanD, Ilyinka Village surroundings, Komissarovka River valley; sandy beaches on banks of the Komissarovka River upwards from the village; 1 ad, 5 tracks, 1 clutch, 20.06.2017.

*31. KhanD, Lublino Village surroundings, Komissarovka River valley; sandy beaches on banks of the Komissarovka River; 2 ad, 15 tracks, 1 clutch, 20.06.2017.

*32. KhanD, Lublino Village surroundings, Komissarovka River valley; sandy beaches on banks of the Komissarovka River; 2 tracks, 20.06.2017.

*33. KhanD, Ilyinka Village surroundings, Komissarovka River valley; sandy beaches on banks of the Komissarovka River to the west from automobile bridge; 5 tracks, 22.06.2017.

*34. KhanD, Ilyinka Village surroundings, Komissarovka River valley, Iliynskie Lakes along the highway «Kamen-Rybolov - Turiy Rog»; some ad, annually last 5 years (E.I. Sadovnikov, 2017: personal communication).

*35. KhanD, Ilyinka Village surroundings, Komissarovka River valley, sandy beaches on banks of the Komissarovka River by the railway bridge; 2 tracks, 22.06.2017.

36. KhanD, «Devichy peski» Cape, Regional Nature Landmark, Khanka Lake shore, sandy beaches to the north from Novo-Nikolaevka Village; 2 ad, July, 2017 (V.M. Kozyrev, 2017: personal communication).

*37. KhorD, Nesterovka Village surroundings, Nesterovka River valley; bayous and channels; some ad, annually (N.I. Mikov, 2017: personal communication).

*38. KhorD, Nesterovka Village surroundings, River Krinichnaya, tributary of Melgunovka River; some ad, annually (N.I. Mikov, 2017: personal communication).

*39. KhorD, Luchki Village surroundings, small lakes and isolated tributary in the valley of the River Berezovka, in the village's vicinity; some ad, annually (N.I. Mikov, 2017: personal communication).

40. CherD, surroundings of Khalkidon Village, bayous and tributaries of River Ilistaya; some ad, annually (Yu.N. Glushchenko, 2018: personal communication).

*41. KhorD, Yaroslavsky Village surroundings, Yaroslavsky's sludge tank-pits; some ad, more than 20 years (S.A. Samoshkina, 2016: personal communication).
42. KirD, Ussuri River valley, $20 \mathrm{~km}$ to the north from Shmakovka resort; sandy-pebbly isle on the river; 1 female on clutching, 18.06.2017 (E.Yu. Doroshenko, 2017: personal communication, photo).

*43. PozhD, Verkhny Pereval Village surroundings, Alchan River valley with lakes and mari opposite to the village; some ad, annually (Yu.B. Shibnev, 2015: personal communication).

44. PozhD, Verkhny Pereval Village surroundings, Bikin River valley, channel and the dike in the village; some ad, annually (pupils of Verkhny Pereval Village, 2015: personal communication).

*45. PozhD, between Verkhny Pereval and Krasniy Yar settlements, River Bikin; near the mouth of the River Sazanya, pebbly river bank; 1 female on clutching, June 2014 (I.S. Sheremetyev, 2015: personal communication).

Takydromus wolteri (Fischer, 1885) (Fig. 3)

46. ArCD, Arseniev City surroundings, slopes of Obzornaya Mt., secondary broadleaved forest of the complex composition, $2 \mathrm{sad}, 18.05 .2004 ; 1 \mathrm{sad}, 1 \mathrm{ad}$ (female), 07.07.2005; 17 juv, 29.08.2005; 1 ad (male), 1 sad., 11 juv, 30.08.2005; 1 ad (male), 03.06.2006; 11 juv, 3 sad., 02.10.2006; 3 ad (1 male and 2 female), 3 sad., 01.05.2009; $1 \mathrm{ad}$ (male), 10.05.2009; $1 \mathrm{ad}$ (male), 13.06.2009; 6 sad., 03.10.2009; 5 sad., 04.10.2009; 6 sad., 09.05.2010; 1 ad (male), 30.05.2011; 3 ad (male), 9 sad and 13 juv, 26.08.2011.

47. ArCD, Arseniev City surroundings, western slope of Uvalnaya Mt., secondary broadleaved forest of complex composition of power transmission line; 1 ad (male), 26.08.2004.

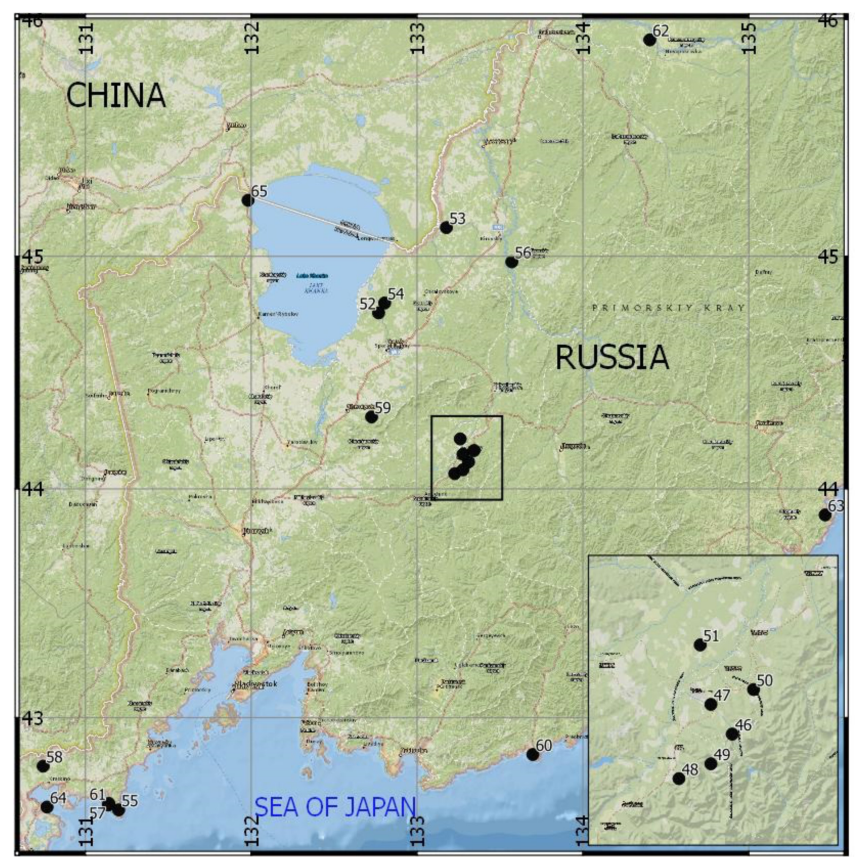

Fig. 3. Findings of Takydromus wolteri on the Primorsky Krai (Russia). 
48. AnD, Taezhka Village surroundings, countryside, 1 ad (male), 31.05.2006.

49. AnD, upper reach of the Taezhka Creek, secondary broadleaved forest of complex composition; 1 ad (female), 13.06.2006.

50. YakD, Sysoevka Village surroundings, fineleaved forest on the border with agricultural lands, nearby artificial lake; $3 \mathrm{sad}, 06.05 .2007 ; 2$ ad, 27.05.2011; 4 ad (3 male and 1 female), 9 sad, 1 juv, 25.08.2013.

51. ArCD, Karasikovo Lake surroundings, collective farm fields; 1 sad, 04.05.2006 (L.A. Danilevich, 2006: personal communication).

52. SpD, Gayvoron Village surroundings, buffer zone of KhankSNR, Spasovka River valley, mixed herbs, sedge-reed meadows; 1 ad, 1995 (Yu.N. Glushchenko, 2005: personal communication). Gayvoronskaya hill, oak rare forest; 1 ad 02.06.2005; 1 sad, 3 juv, 04.09.2005; 1 male, 7 juv, 06.10.2005; 1 ad, $1 \mathrm{sad}, 03.05 .2006$; 1 ad (male), 4 sad, 21.04.2016.

53. KirD, KhankSNR, Pavlo-Federovka Village surroundings, Sungacha River valley, oak rare forests combined with flood meadows; $6 \mathrm{sad}, 7 \mathrm{juv}$, 20.09.2002; 1 ad, 1 sad, 2 juv, 16.09.2003; 1 ad, 19 sad, 4 juv, 17.09.2003.

54. SpD, Sosnovka Village surroundings, buffer zone KhankSNR, mixed herbs, sedge-reed meadows; $1 \mathrm{sad}, 05.04 .2006$ (K.N. Mrikot, 2006: personal communication).

55. KhasD, of Vityaz Village surroundings, oak rare forest combined with shrub thicket; 2 ad (female), 28.09.2008.

*56. KhasD, Andreevka Village surroundings, oak rare forest on the border with stone shore of the Sea of Japan; 1 ad 09.05.2014.

*57. KirD, Podgornoe Village surroundings, secondary mixed broadleaved forest; 1 individual, 21.09.2015 (N.V. Kameneva, 2015: personal communication, photo).

*58. KhasD, LLSNP, mean current of the River Tsukanovka, oak rare forest combined with shrub thicket; 1 ad 29.09.2015.

*59. CherD, Gorniy Khutor Village surroundings, nearby helicopter pad; 1 ad (female), 29.04.2016 (A.V. Kaplunenko, 2016: personal communication, photo).

*60. LazD, Kievka Village surroundings, the forest near MBS «Zapovednoe» FEFU; 1 ad (female), 01.07.2017 (D.A. Sokolova, 2017: personal communication, photo).

61. KhasD, Risovaya Pad Settlement, oak light forest; 1 ad summer 2016 (T.A. Kushnir, 2016: personal communication).
*62. KrD, Goncharovka Village, the yard of a local citizen; 1 ad19.05.2017 (D. Podgaynoy, 2017: personal communication, photo).

*63. OlD, Timopheevka Village surroundings, shore of the Sea of Japan, 1 ad 18.05.2017 (P.A. Saveliev, A.V. Savelieva, 2017: personal communication, photo).

64. KhasD, Mramornaya Bay shore of the Sea of Japan; 1 ad 2016 (Yu.N. Glushchenko, 2016: personal communication).

*65. KhasD, Turiy Rog Village, 1 ad in zoological museum in the biology class of secondary municipal school (Turiy Rog Village), 22.06.2016.

\section{Oocatochus rufodorsatus (Cantor, 1842)} (Fig. 4)

*66. KhanD, Platonovo-Alexandrovskoe Village surroundings, abandoned railway to the north from village, stone steep slope between railway and the shore of Lake Khanka with rare grass and single small elms; 2 ad, 31.08.2016.

*67. KhanD, Platonovo-Alexandrovskoe Village surroundings, abandoned railway to the south of the village; $1 \mathrm{ad}, 01.09 .2016$.

*68. KhanD, Turiy Rog Village; 1 ad in zoological museum in the biology class of secondary municipal school (Turiy Rog Village), 22.06.2016.69. KhanD, Dvoryanka Village surroundings, Komissarovka River valley, forest-steppe fragment; $1 \mathrm{ad}$, 16.06.2017.

*70. KhanD, Komissarovo Village surroundings, Komissarovka River valley, on the border of flood plain with multiple bayous and a hill, covered with oak and pine forest; $2 \mathrm{ad}, 1 \mathrm{sad}, 17.06 .2017$.

*71. KhanD, Komissarovo Village, Komissarovka River valley, school's garden; $1 \mathrm{ad}$, 19.06.2017.

*72. KhanD, Ilyinka Village, Komissarovka River valley, private sector, on the kitchen garden of the local citizen; $1 \mathrm{ad}, 22.06 .2017$.

*73. KhanD, Ilyinka Village, Komissarovka River valley, mound of railway bridge across the Komissarovka River; 1 ad, 22.06.2017.

*74. NadD, Senokosnoe Village, Vtoraya Rechka River downstream part, flood sedge-reed meadow; 2 ad, 18.09.2016; 1 ad, 21.09.2016.

*75. KhasD, Kravtsovka Village surroundings, mixed broadleaved forest, automobile bridge through the Ponin Creek; 1ad, Mid-June 2011.

*76. PozhD, Verkhniy Pereval Village surroundings, swampy lakes between Verkhniy Peraval Village and the River Alchan; Ordinary, reported several times (Yu.B. Shibnev: oral report). 


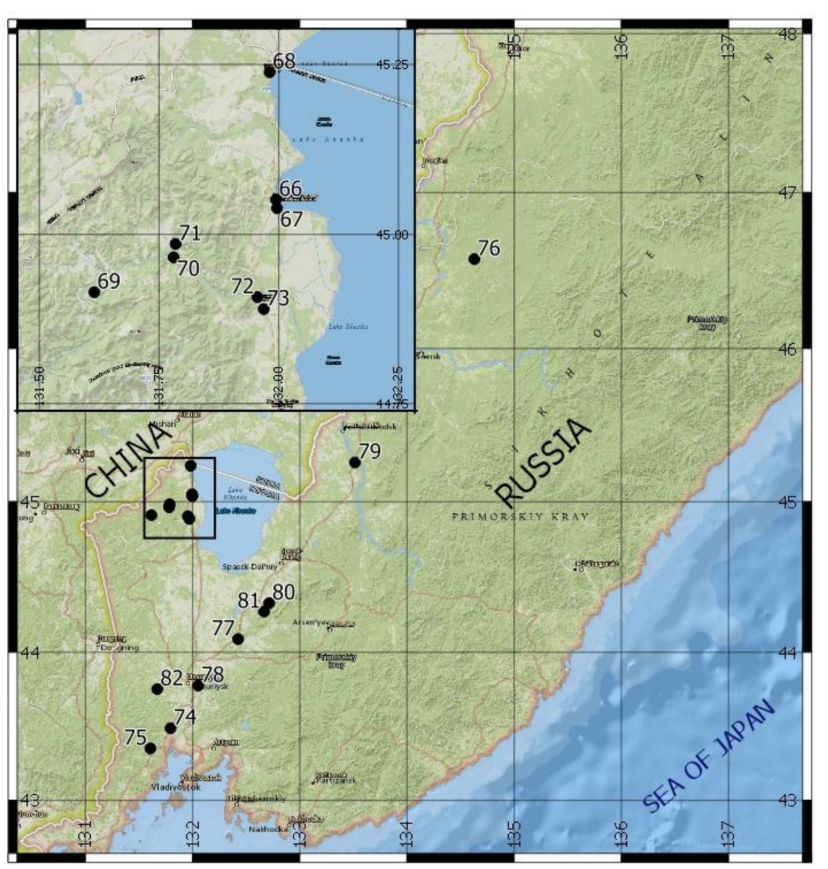

Fig. 4. Findings of Oocatochus rufodorsatus in the Primorsky Krai (Russia).

*77. MikhD, River Lyalichi Village, Ilyistaya River floodplain, bank of the river with reed; $1 \mathrm{ad}, 23.05 .2015$ (local citizens during fishing, 2015, photos)

*78. UsCD, Ussuriysk City, cardboard factory surroundings, near the foot of steep slope with oak, 1 ad, Mid-summer 2002 (Yu.N. Glushchenko, 2018: oral report).

*79. LesD, Gornye Kluchi Village surroundings, Ussuri River valley, right bank of River Ussuri, bayou ponds on the border with forests; 3 ad, July 1981; 3 ad, end of June 2007 (Yu.N. Glushchenko, 2018: oral report).

80. CherD, between Gorniy Khutor and Chernigovka Villages, Medveditsa River valley, fineleaved forest and bayou ponds; some ad, during every field work in 1977-1982 (Yu.N. Glushchenko, 2018: oral report).

81. CherD, Gribnoe Village surroundings, Chernigovka River floodplain, fineleaved forest, bayou ponds; some ad, during every field work in 1977-1982 (Yu.N. Glushchenko, 2018: oral report).

*82. UsCD, Krounovka Village surroundings, Krounovka River floodplain, near with the bayou; $1 \mathrm{ad}$, beginning of June 1986 (Yu.N. Glushchenko, 2018: oral report).

Hebius vibakari (Boie, 1826) (Fig. 5)

*83. NadD, NPSLL, middle current of the River Malaya Ananievka, floodplain fineleaved forest; $1 \mathrm{ad}, 12.07 .2011$.

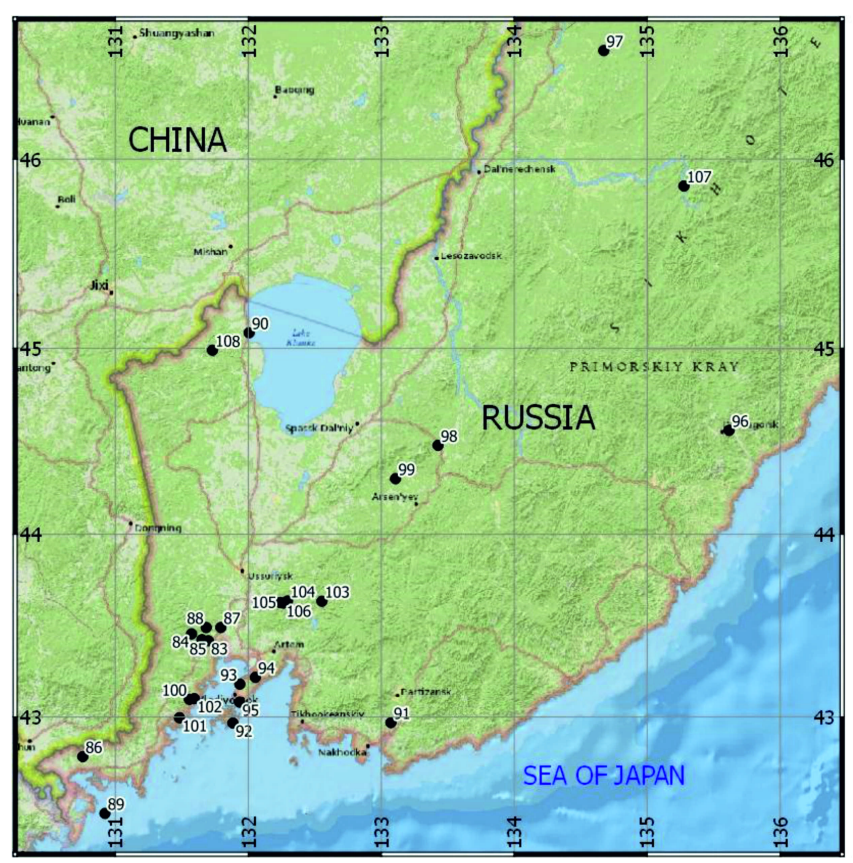

Fig. 5. Findings of Hebius vibakari in the Primorsky Krai (Russia).

*84. NadD, NPSLL, middle course of the River Malaya Ananievka, coniferous-broadleaved forest; 1 ad, 28.05.2015; 2 ad, 29.05.2015.

*85. NadD, NPSLL, middle course of the River Malaya Ananievka, coniferous-broadleaved forest; 1 ad. swam over the river, 19.08.2015.

*86. KhasD, NPSLL, Sukhaya Rechka River valley, affluent of the River Tsukanovka, lower part of north-eastern slope of Luna Mt; 1 ad. on the path, 26.09.2015.

*87. NadD, Senokosnoe Village, River Vtoraya Rechka downstream part, floodplain sedge-reed meadow; 1 ad, 16.09.2016; 1 ad, 01.10.2016.

*88. NadD, NPSLL, middle course of the River Vtoraya Rechka, coniferous-broadleaved forest; lad (male), 19.09.2016.

89. KhasD, FEMSNR, Furugelm's Island, broadleaved forest; single individuals multiple times in 1980-1990 (Yu.V. Shibaev, 2018: oral report).

*90. KhanD, Novokachalinsk Village surroundings, Khanka Lake shore, «Bolshoy Kamen» Cape, oak light forest, occasionally rock stones; 1 ad, middle of 2000s (Yu.D. Kulibaba, Yu.A. Chistyakov, 2016: oral report).

*91. ParD, Boets Kuznetsov Village surroundings, secondary oakery forest; $4 \mathrm{ad}, 1 \mathrm{sad}$, 29.06.2017.

*92. VICD, south-eastern shore of Russky Island, on the border with secondary oakery forest and stone seashore; more than 20 ad, Mid-July 2017.

*93. V1CD, northern part of Vladivostok City, on the slope of the hill, fragments of sec- 
ondary oakery forest among the houses of private sector, 5 individuals, June 2008 (A.P. Levus, 2015: oral report).

*94. V1CD, «Sputnik» Railway Station surroundings, edge of coniferous-broadleaved forest near the Bogatinsky water storage-basin; more than 20 ad, 17.09.2016.

*95. V1CD, «Morskoe» graveyard of Vladivostok City, secondary oakery forest; 2 ad, July 2009.

*96. D1CD, country sites towards Krasnorechensk Town, secondary broadleaved forest; more than 10 ad, Mid-July 2016.

*97. PozhD, Verhny Pereval Village surroundings, lower part of the hill, covered with oaks; $1 \mathrm{ad}$, July 1976 (Yu.N. Glushchenko, 2018: oral report).

*98. YakD, Siniy Ridge, coniferous-broadleaved forest, floodplain of the right affluent of the Yakovlevka River; 2 ad, 05.08.2001.

*99. YakD, Siniy Ridge, Sinegorka River floodplain, coniferous-broadleaved forest; $1 \mathrm{ad}$, 07.08.2004.

100. KhasD, KpSNR, middle course of Kedrovaya River, floodplain fineleaved forest; stone bank of the river; $1 \mathrm{ad}, 29.07 .2007 ; 1 \mathrm{ad}, 01.08 .2007 ; 1$ ad, 09.09.2008.

*101. KhasD, Narva River mouth, mixed herbs meadow; 1 ad, 14.06.2005.

*102. KhasD, Primorsky Settlement; the yard of low-rise living sector; 3 ad (male), 1 ad (female), 16.07.1986.

103. ShkD, UssSNR, «Suvorovskoe» Forestry, Suvorovka River valley, floodplain fineleaved forest; $1 \mathrm{ad}, 19.06 .1990 ; 1 \mathrm{ad}, 22.06 .1994 ; 1 \mathrm{ad}$, 17.08.1995.

104. UsCD, UssSNR, «Komarovskoe» Forestry, Komarovka River upper course, coniferousbroadleaved forest; 1ad (female), 13.06.1986; 1 sad, 06.08.1986; 1ad (male), 22.08.1986; 1 ad, 30.06.1994; 1 ad (male), 18.07.1997.

105. UsCd, Kaymanovka Village, Komarovka River valley; lad (male), lad (female), 04.07.1986; $1 \mathrm{ad}, 03.08 .1986 ; 1 \mathrm{ad}, 03.08 .1990$; 1 ad, 03.07.1991; 1 ad, 13.06.1994; 1 male, 20.06.1995; 1 ad, 27.06.1995; 1 ad, 29.09.1995; 1 ad, 06.09.1996; 1 ad, 15.07.1997; 1 ad, 29.07.1997.

106. UsCD, Kaymanovka Village surroundings, Komarovka River valley, coniferous-broadleaved forest; $1 \mathrm{ad}, 18.07 .1997$; 1 juv, 28.09.1997; $1 \mathrm{ad}, 17.06 .2012$.

*107. KrD, Dalniy Kut Village surroundings, Bolshaya Ussurka River valley, near the foot of the hill, oak forest; $1 \mathrm{ad}, 2015$ (V.P. Gergel, 2016: oral report).
108. KhanD, Komissarovo Village surroundings, Komissarovka River valley, old quarry near secondary oak forest; 1 ad, 02.10.2014 (N.E. Pokhilyuk, 2018: oral report).

\section{Discussion}

Studies of the long-tailed salamander of the genus Onychodactylus showed $O$. fischeri to occupy the Russian territory only in the central and southern parts of the Sikhote-Alin mountain system (Poyarkov et al., 2012). Therefore, organising a monitoring state of the species in Primorsky Krai is an urgent issue, moreover its population and distribution were assessed for the last time nearly 20 years ago (Maslova, 2001; Kuzmin \& Maslova, 2005). The investigation of the south-eastern part of $O$. fischeri's habitat in 2016-2017 provided new information about its distribution (Sokolova et al., 2017). The species was found on the Partizansky Ridge (point 3) for the first time, thus extending the distribution range of this tailed amphibian in the southeastern direction by $40-50 \mathrm{~km}$. In addition, O. fischeri was found on the upper course of many creeks and rivers in the Przhevalsky mountains (Livadiysky Ridge, Bolshoy Vorobey Ridge, Lozoviy Ridge; points 1, 2, 4-10). Already in the 1990 s, it was planned to organise Yuzhno-Primorsky Natural Park in this picturesque touristattracting mountain system and the project was developed, but it was not implemented (Bersenev $\&$ Khristoforova, 2016). At present, there are concentrated several potential threats for sustainable existence of $O$. fischeri in the southeastern part of Primorsky Krai, namely: high recreational loads (mountain skiing, tourist camping, etc.), largescale, often illegal woodcutting, planned construction of petrochemical industrial facilities near Nakhodka City. Moreover, the administration of Primorsky Krai is developing the project «Bolshoy Vladivostok» which implies merging the territory between Vladivostok and Nakhodka into one municipal area (https://primamedia.ru/news/44721/).

To date, the vulnerability of the Russian population of Pelodiscus maackii inhabiting the northeastern border of its habitat remains on a rather high level. A dramatic water rise in Lake Khanka, which began in 2014 and is continuing nowadays, was added to the known natural and anthropogene threats to the species. As a result, most places of P. maackii's reproduction has been submerged in KhankSNR (Maslova \& Vorobieva, 2016) and eventually made turtles seek for new places for laying their eggs. Our data show a current distribution of $P$. maackii in the 
western part of the lake. Banks in the middle and lower course of the River Komissarovka (points 2635), Vtoraya Rechka River mouth (point 11), two sandy beaches on Khanka Lake's shore between Platonovo-Aleksandrovkoe and Novokachalisk villages (points 12,15) as well as one sandy beach between Kamen-Rybolov and Troitskoe villages (points 16, 17) are highly important for the species' breeding. The obtained data on the distribution of this species will allow organising new Protected Areas, playing a key role for reproduction to conserve the turtle population on Khanka.

Distribution borders of Takydromus wolteri in the northern part of its habitat still remain unclear (Semenishcheva \& Maslova, 2013). For the first time, reliable data on $T$. wolteri habitat have been obtained for KhanD (point 65), KrD (point 62) and OlD (point 63) which expand the western, northern and eastern borders of the lizard's habitat in Russia.

In Primorsky Krai, Oocatochus rufodorsatus is occasionally found on the southern part of the Sea of Japan coast, along the river valleys of Sungacha and Ussuri as well as along river valleys and lentic ponds in plain regions of the south-western part of Primorye (Emelyanov, 1929; Korotkov, 1985; Adnagulov \& Oleinikov, 2006; Kharin, 2011). Two places harbour locally a high population of O. rufodorsatus: along the River Komissarovka (points 69-73), Lake Khanka shore (points 66-68) (KhanD) and in the low current of the River Vtoraya Rechka (point 74) (NadD).

The high number of findings of the reptile species Oocatochus rufodorsatus and Pelodiscus maackii in the basin of the River Kovissarovka of KhanD is a strong argument for creating a net of Protected Areas, primarily, along the River Komissarovka and on single fragments of the western shore of Lake Khanka, which are not included into the territory of KhankSNR (Maslova, 2016, 2017; Makarchenko et al., 2017).

Unfortunately, the Bikin National Park, founded in 2015, has no effect on the conservation of Pelodiscus maackii, because the main habitats and places of the reproduction are south of the western border of this Protected Area (points 43, 44, 45). According to zoologists working along the River Bikin, sometimes turtles go up the river from Krasniy Yar Village almost to Svetlovodnaya River mouth, but rather rare (Maslova \& Seredkin, 2016). The same counts for the territory of the Udegeyskaya Legenda National Park, founded in 2007, situated on the River Bolshaya Ussurka. Op- timal habitat conditions for $P$. maackii correspond only to the middle and lower course of the river.

Hebius vibakari is one of the least studied species (Dunaev \& Orlova, 2014). That is why many Russian herpetologists consider this species to include into the Red Data Book of the Russian Federation (2001). The first recommendations in this respect were given in 1978 (Borkin \& Krever, 1987), while Emelyanov (1929) pointed out this species was found in the southern part of Primorsky Krai «...in great numbers...». Kharin (2011) noted that «...the species is common on the seashore but rather stealthy...». Even though this species is frequently called «rare» in literature, our findings prove incorrectness of such definition for Primorsky Krai. We showed that south and central Primorye is populated rather well with this species and in some places exhibits high populations (points 91, 92, 93, 94, 96). A high occurrence of $H$. vibakari is indicated for anthropogene biotopes. It inhabits not only populated country sites (dacha) and villages, but also edges of big cities (points 93, 95). H. vibakari has been found in UssSNR (points 103-106), LLSNP (points 83-86, 88) and KpSNR (points 100-102) for several years.

\section{Conclusions}

Information on 108 findings is reported for five rare and endangered species of amphibians and reptiles inhabiting Primorsky Krai: Onychodactylus fischeri, Pelodiscus maackii, Takydromus wolteri, Oocatochus rufodorsatus, and Hebius vibakari. Point 61 is a new place of occurrence of these species, resulting in clarifying the borders of their habitats and making clear the distribution of rare herpetofauna species in the Primorsky Krai. Information on new habitats provides a better knowledge of the distribution of rare amphibians and reptiles, whose north-eastern habitat range touches southern part of the Russian Far East.

The presented data are relevant for field guides, reference books and for developing complex nature conservation programmes. The results can serve for a database of Far Eastern amphibians and reptiles. The obtained information will favour the execution of «Strategy for conservation of rare and endangered animals, plants and fungi in Russian Federation till 2030» (approved by the Russian Federation Government on February 17, 2014, \#212-r), because most part of the Far Eastern flora and fauna is threatened by degradation and habitat depletion due to large-scale industrial development of these lands. The data 
provide a clearer picture of treats for taxa in the region and serves as an instrument to evaluate the species status on the IUCN Red List.

Several protected areas were analysed with respect to their role in conserving rare species of the Far Eastern herpetofauna. UssSNR, LLSNP and KpSNR were regarded as crucial for the conservation of Hebius vibakari.

«Bikin» and «Udegeyskaya Legenda» national parks within their current borders show they have no effect on conservation of Pelodiscus maackii and Oocatochus rufodorsatus populations in the river basins of Bikin of Bolshaya Ussurka lying more to the west of the mentioned protected areas. It is necessary to establish new Protected Areas in Primorsky Krai in various parts: in the western part, in the Komissarovka River basin to preserve the populations of $O$. rufodorsatus and P. maackii as well as in the south-eastern part, and to protect Onychodactylus fischeri on the Livadiysky Ridge.

\section{Acknowledgements}

We are grateful to Yu.N. Glushchenko, M.B. Manaev, P.T. Kuznetsov, V.F. Noskov, A.P. Levus, N.I. Mikov, I.S Sheremetiev, Yu.V. Shibaev, N.E. Pokhilyak for the valuable information on certain reptile species; Yu.E. Dochevoy, V.M. Kozyrev, E.I. Sadovnikov, Yu.K. Novichikhin, V.M. Kryukov, N.N. Avstrievskaya, A.I. Bykovsky, S.P. Narchuk, E.N. Sharafutdinova, I.N. Otstavnykh, O.E. Khimich for the help during field research.

\section{References}

Adnagulov E.V. 2008. On the ways to census Chinese softshell turtle Pelodiscus sinensis (Reptilia: Trionychidae). In: The Problems of Herpetology: Proceedings of the $3^{\text {rd }}$ Meeting of the Nikolsky Herpetological Society. Saint-Petersburg. P. 11-15. [In Russian]

Adnagulov E.V. 2017. Annotated list of Amphibian and Reptile species of Far East Russia. Current Studies in Herpetology 17(3/4): 95-123. DOI: 10.18500/1814-60902017-17-3-4-95-123 [In Russian]

Adnagulov E.V., Maslova I.V. 2005. On the Distribution of Pelodiscus sinensis (Wiegmann, 1834) (Testudines: Trionychidae) in the Russian Far East. Russian Journal of Herpetology 12: 117-119.

Adnagulov E.V., Oleinikov A.Yu. 2006. On the Distribution and Ecology of Amphibians and Reptiles in the South of the Russian Far East. Russian Journal of Herpetology 13(2): 101-116.

Bersenev Yu.I., Khristoforova N.K. 2016. Protected Areas of Primorsky Krai. Vladivostok: Vladivostok Publishing. 68 p. [In Russian]

Borkin L.J., Krever V.G. 1987. Protection of amphibians and reptiles in reserves of Russian Soviet Federative Social- ist Republic. In: I.S. Darevsky, V.G. Krever (Eds.): Amphibians and Reptiles of Protected Areas. Moscow. P. 39-53. [In Russian]

Buldovskiy A.T. 1936a. On organisation of turtle reserve and bird sanctuary on Khanka Lake. In: N. Protanskiy (Ed.): Protected Areas of Far Eastern Krai: Notes of Primorsky branch of State Geographical Society 6(23): 41-47. [In Russian]

Buldovskiy A.T. 1936b. On biology and industrial exploitation of soft-shelled turtle Amyda maakii (Brand.). Proceedings of FEF AS USSR 1: 62-102. [In Russian]

Chen X.-J., Xu X.-F., Ji X. 2003. Influence of body temperature on food assimilation and locomotor performance in white-striped grass lizards, Takydromus wolteri (Lacertidae). Journal of Thermal Biology 28(5): 385-391. DOI: $10.1016 / \mathrm{S} 0306-4565(03) 00022-6$

Cherepanov G.O. 1990. On the biology of Chinese Softshell Turtle on Khanka Lake. Bulletin of Leningrad State University 3(2): 23-28. [In Russian]

Dunaev E.A., Orlova V.F. 2014. Snakes. Species of the fauna of Russia: Atlas-determinant. Moscow: Fiton. 120 p. [In Russian]

Emelyanov A.A. 1929. Snakes of Far East. Vladivostok: Vladivostok Department of State Russian Geographical Society. 207 p. [In Russian]

Frost D.R. 2017. Amphibian Species of the World: Online Reference. Version 6. Electronic Database. New York: American Museum of Natural History. Available from http://research.amnh.org/herpetology/amphibia/index. html (Retrieved on 07.04.2018).

Jin S.-D., Han S.-W., Shin H.C., Paik I.-H., Paek W.-K., Lee H., Kim I.-K. 2013. Phylogeographical Analysis of Eremias argus in Yoobu-do Island and Sohwang Sand Dune, Korea. Journal of Asia-Pacific Biodiversity 6(4): 455-458. DOI: 10.7229/jkn.2013.6.4.00455

Guo P., Zhu F., Liu Q., Zhang L., Li, Y.X., Huang Y.Y., Pyron R.A. 2014. A taxonomic revision of the Asian keelback snakes, genus Amphiesma (Serpentes: Colubridae: Natricinae), with description of a new species. Zootaxa 3873(4): 425-440. DOI: 10.11646/zootaxa.3873.4.5

Kharin V.E. 2011. An annotated catalogue of amphibians and reptiles of Far-Eastern Marine Biosphere Reserve FEB RAS. In: A.N. Tyurin (Ed.): Biota and Environment of Nature Reserves of Far East. Vol. 1. P. 30-48. [In Russian]

Kharin V.E., Akulenko M.V. 2008. Rare and little-known snakes in North-Eastern Eurasia. 1. On a new record of slender racer - Hierophis spinalis (Colubridae) in the Russian Far East. Current Studies in Herpetology 8(2): 160-169. [In Russian]

Korotkov Yu.M. 1985. Terrestrial reptiles of Far East. Vladivostok: Far Eastern Publishing. 133 p. [In Russian]

Ku S.K., Lee H.S. 2004. The distribution and frequency of endocrine cells in the splenic lobe of grass lizard (Takydromus wolteri). An immunohistochemical study. European Journal of Histochemistry 48(4): 429-436. 
Kuzmin S.L. 2012. Amphibians of the former USSR. Moscow: KMK Scientific Press Ltd. 370 p. [In Russian]

Kuzmin S.L., Maslova I.V. 2005. Amphibians of the Russian Far East. Moscow: KMK Scientific Press Ltd. 434 p. [In Russian]

Lee H.S., Ku S.K. 2004. An immunohistochemical study of endocrine cells in the alimentary tract of the grass lizard, Takydromus wolteri Fischer (Laceridae). Acta Histochemica 106(2): 171-178. DOI: 10.1016/j.acthis.2003.10.008

Makarchenko E.A., Vshivkova T.S., Gansey K.S., Klyshevskaya S.V., Kozhevnikov A.E., Maslova I.V., Nazarenko A.A., Prozorova L.A., Prokopets S.D., Shabalin S.A., Shed'ko S.V. 2017. About Protected Area creating in the basin of Lake Khanka. Bulletin of FEB RAS 2: 115141. [In Russian]

Maslova I.V. 2008. Mountain grass lizard in Khankaisky Nature Reserve. In: The Problems of Herpetology: Proceedings of the $3^{\text {rd }}$ Meeting of the Nikolsky Herpetological Society. Saint-Petersburg. P. 281-285. [In Russian]

Maslova I.V. 2001. New Data on the Distribution of Onychodactylus fischeri in the Primorye. In: Proceedings of the $1^{\text {st }}$ Meeting of the Nikolsky Herpetological Society. Moscow: Moscow State University. P. 190-192. [In Russian]

Maslova I.V. 2017. Problem of biodiversity conservation in the western Prikhankovie (Primorsky Krai, Russia). In: E.Ya. Frisman (Ed.): XII Far Eastern conference on $\mathrm{Na}$ ture Conservation Problems: Materials of the Scientific Conference in Birobidzhan (10-13 October, 2017). Birobidzhan: ICARP FEB RAS. P. 134-136. [In Russian]

Maslova I.V. 2006. Amphibians and reptiles. In: A.A. Nazarenko (Ed.): Vertebrates of Nature Reserve «Khankaisky» and Prikhankayskaya Lowland. Vladivostok: Idea Press. P. 67-76. [In Russian]

Maslova I.V. 2016. The protection of amphibians and reptiles in the Russian Far East. Nature Conservation Research 1(3): 26-35. DOI: 10.24189/ncr.2016.024

Maslova I.V., Seredkin I.V. 2016. Amphibians and Reptiles of the Bikin National Park (Primorsky Krai). Biodiversity and Environment of Far East Reserves 1(8): 44-59. [In Russian]

Maslova I.V., Vorobieva P.A. 2016. How to keep the population of the Chinese Soft-shell Turtle on Khanka Lake. In: T.S. Vshivkova (Ed.): Nature without borders: Proceedings of X International ecological forum (20-21 October, 2016). Vladivostok: Print Mart. P. 140-145. [In Russian]

Ota H., Honda M., Chen S.-L., Hikida T., Panha S., Oh H.-S., Matsui M. 2002. Phylogenetic relationships, taxonomy, character evolution and biogeography of the lacertid lizards of the genus Takydromus (Reptilia: Squamata): A molecular perspective. Biological Journal of the Linnean Society 76(4): 493-509. DOI: 10.1046/j.10958312.2002.00084.x

Poyarkov N.A., Che J., Min M.-S., Kuro-o M., Yan F., Li Ch., Iizuka K., Vieites D.R. 2012. Review of the sys- tematics, morphology and distribution of Asian Clawed Salamanders, genus Onychodactylus (Amphibia, Caudata: Hynobiidae), with the description of four new species. Zootaxa 3465: 1-106.

Ra N.-Y., Lee J.-K., Lee J.-H., Kim J.-K., Kim D.-I., Kim B.N., Kim I.-H., Park D. 2011. Ectoparasites: Immature Japanese hard ticks (Ixodes nipponensis; Acari: Ixodidae) on Korean lizards. Journal of Ecology and Field Biology 34(3): 307-313. DOI: 10.5141/JEFB.2011.033

Red Data Book of Primorsky Krai. Animals: Rare and endangered plant and animal species. Vladivostok: AVK Apelsin, 2005. 448 p. [In Russian]

Red Data Book of the Russian Federation. Animals. Moscow: Astrel, 2001. 860 p. [In Russian]

Semenishcheva E.Yu., Maslova I.V. 2010. On distribution of lizards of genus Takydromus in the southern parts of Russian Far East. Kazan Science 8(1): 57-59. [In Russian]

Semenishcheva E.Yu., Maslova I.V. 2013. Biotope distribution of two lizards species of the genus Takydromus near Arseniev. In: Modern herpetology: problems and ways of their solutions. Proceedings of the First International Conference of the Young Herpetologists of Russia and neighboring countries (Saint-Petersburg, Russia, 25-27 November, 2013). Saint-Petersburg. P. 134-136. [In Russian]

Sokolova D.A., Maslova I.V., Manaev V.B. 2017. On distribution of Onychodactylus fischeri in the south-eastern part of Primorsky Krai. In: Procceedings of XII Far Eastern conference on reserve management. Birobidzhan: ICARP FEB RAS. P. 114-115. [In Russian]

Solkin V.A. 1990. About place of Red-banded Snake Dynodon rufosonatum in the herpetofauna of USSR. Zoologicheskii Zhurnal 69(11): 144-145. [In Russian]

Suh J.-H., Kim H.-C., Yun S.-M., Lim J.-W., Kim J.-H., Chong S.-T., Kim D.-H., Kim H.-T., Kim H., Klein T.A., Johnson J.L., Lee W.-J. 2016. Detection of SFTS Virus in Ixodes nipponensis and Amblyomma testudinarium (Ixodida: Ixodidae) Collected from Reptiles in the Republic of Korea. Journal of Medical Entomology 53(3): 584-590. DOI: 10.1093/jme/tjw007

Uetz P., Freed P., Hošek J. (Eds.). 2018. The Reptile Database. Available at: http://reptile-database.org (Retrieved: 28.02.2018).

Xu X.-F., Wu Y.-L., Ou Y.-Y., Wu L.-S. 2008. Embryonic growth and mobilization of material and energy in oviposited eggs of the white-striped grass lizards Takydromus wolteri. Acta Ecologica Sinica 28(10): 4782-4786.

Yu D.-N., Ji X. 2013. The complete mitochondrial genome of Takydromus wolteri (Squamata: Lacertidae). Mitochondrial DNA 24(1): 3-5. DOI: 10.3109/19401736.2012.710223

Zhang Y.-P., Ji X. 2004. The thermal dependence of food assimilation and locomotor performance in southern grass lizards, Takydromus sexlineatus (Lacertidae). Journal of Thermal Biology 29(1): 45-53. DOI: 10.1016/j.jtherbio.2003.10.007 


\title{
О РАСПРОСТРАНЕНИИ РЕДКИХ И ИСЧЕЗАЮЩИХ АМФИБИЙ И РЕПТИЛИЙ ПРИМОРСКОГО КРАЯ (ДАЛЬНИЙ ВОСТОК, РОССИЯ)
}

\author{
И. В. Маслова ${ }^{1}$ Е. Ю. Портнягина², Д. А. Соколова², П. А. Воробьева ${ }^{2}$, \\ М. В. Акуленко ${ }^{3}$, А. С. Портнягин ${ }^{2,4}$, А. А. Сомов ${ }^{5}$ \\ ${ }^{1}$ Федеральный научный центр биоразнообразия наземной биоты Восточной Азии ДВО РАН, Россия \\ e-mail: irinarana@yandex.ru \\ ${ }^{2}$ Дальневосточный федеральный университет, Россия \\ e-mail:semenkaty@gmail.com,daria_1844@mail.ru,medusa8800@mail.ru \\ ${ }^{3}$ ООО «Гидротехника», Россия \\ e-mail:animals06@bk.ru \\ ${ }^{4}$ Институт химии Дальневосточного отделения РАН, Россия \\ e-mail:arsuha@gmail.com \\ ${ }^{5}$ Тихоокеанский научно-исследовательский рыбохозяйственный центр, Россия \\ e-mail: alekseysomoff@gmail.com
}

В статье представлена информация о новых находках пяти редких и исчезающих видов амфибий и рептилий Приморского края: Onychodactylus fischeri, Pelodiscus maackii, Takydromus wolteri, Oocatochus rufodorsatus, Hebius vibakari. Для них выявлены новые местонахождения. Onychodactylus fischeri был впервые обнаружен на территории хребта Партизанский, в результате чего его ареал расширен в юго-западном направлении. Впервые приводятся данные о находках Takydromus wolteri, Oocatochus rufodorsatus и Hebius vibakari в западной части Приморского края. Границы местообитаний Takydromus wolteri в северной части распространения этого вида были расширены в нескольких направлениях: в западном (Ханкайский район), северном (Красноармейский район) и северо-восточном (Ольгинский район). Показана современная картина распространения и мест размножения ханкайской популяции P. maackii, с учётом массового затопления песчаных кос на западном побережье оз. Ханка в 2014-2017 гг. Было отмечено, что реки, впадающие в оз. Ханка с западной стороны, играют важную роль, в качестве места обитания и размножения этого вида. Впервые представлена подробная информация о распространении Hebius vibakari в Приморском крае. Было зафиксировано, что этот вид для южной и центральной частей края обычен и локально многочислен. Было изучено современное состояние популяций отдельных видов в местонахождениях, известных ранее по данным литературы. Несколько особо охраняемых природных территорий были обследованы на предмет эффективности сохранения редких видов герпетофауны Дальнего Востока. Hebius vibakari рассматривается как вид, стабильно встречающийся в государственных природных заповедниках «Уссурийский» и «Кедровая Падь», а также национальном парке «Земля Леопарда». Отмечено, что в пределах своих границ национальные парки «Бикин» и «Удэгейская Легенда» не эффективны в охране популяций Pelodiscus maackii и Oocatochus rufodorsatus, обитающих в бассейнах рек Бикин и Большая Уссурка. Показана актуальность организации новых особо охраняемых природных территорий в западной (бассейн р. Комиссаровка) и юго-восточной (Ливадийский хребет) частях Приморского края.

Ключевые слова: Amphibia, Reptilia, распространение, редкий вид, российский Дальний Восток 